\title{
Engineering building blocks for self-assembling protein nanoparticles
}

Esther Vázquez ${ }^{1,2,3}$, Antonio Villaverde $e^{1,2,3^{*}}$

\begin{abstract}
Like natural viruses, manmade protein cages for drug delivery are to be ideally formed by repetitive subunits with self-assembling properties, mimicking viral functions and molecular organization. Naturally formed nanostructures (such as viruses, flagella or simpler protein oligomers) can be engineered to acquire specific traits of interest in biomedicine, for instance through the addition of cell targeting agents for desired biodistribution and specific delivery of associated drugs. However, fully artificial constructs would be highly desirable regarding finest tuning and adaptation to precise therapeutic purposes. Although engineering of protein assembling is still in its infancy, arising principles and promising strategies of protein manipulation point out the rational construction of nanoscale protein cages as a feasible concept, reachable through conventional recombinant DNA technologies and microbial protein production.
\end{abstract}

\section{Commentary}

Targeted drug and nucleic acid delivery, in which biodistribution is achieved by ligand-receptor interactions, is a promising way to reduce drug toxicity and enhance effectiveness, what is of special relevance for the treatment of cancer and chronic viral diseases, among others. In gene therapy, the term 'artificial viruses' has been proposed to describe virus-like constructs exhibiting specific viral functions that are relevant to cell recognition, penetration and compartment-aimed release of cargo nucleic acids [1-3]. This nanoparticle-based concept, which can be also extended to chemical drug delivery, involves the use of refillable cages and the incorporation of functional agents for cell receptor binding, cellular uptake and eventually endosomal escape and nuclear delivery. Lipidic and polymeric nanoparticles have been under continuous development during the last four decades [4-6], while nanofibers, nanowires, carbon nanotubes and other types of nanosized cages are being progressively incorporated into the drug delivery scenario [7]. The desired molecular organization, size dispersion and geometry of these constructs is achieved by mechanical and chemical approaches, through fine micro- or nanofabrication procedures $[8,9]$.

\footnotetext{
* Correspondence: antoni.villaverde@uab.cat

'Institute for Biotechnology and Biomedicine, Universitat Autònoma de Barcelona, Bellaterra, 08193 Barcelona, Spain

Full list of author information is available at the end of the article
}

Most of these particles are blind; therefore they require to be functionalized with targeting agents for specific cell attachment, being proteins the most efficient, versatile and tunable tools for cell and tissue targeting.

Advances in proteomics and systems biology have permitted to expand the existing catalogues of molecular markers relevant in biomedicine, specially those of interest in cancer diagnosis and therapy [10-14]. In parallel, growing numbers of peptides, antibodies and other protein ligands suitable for cell targeted delivery are becoming available [15-25], supported by the efforts in medical-focused applications of peptide display technologies [20,26-29]. All these findings provide a growing spectrum of therapeutic opportunities in the context of innovative and personalized medicines.

Interestingly, protein-only entities are appealing candidates as building blocks of drug delivery cages $[30,31]$. Their biocompatibility, biological fabrication, functional diversity and versatility of design though protein engineering (assisted by in silico instruments) make them extremely plastic and powerful materials in comparison with liposomes and other types of artificial viruses. Importantly, modular approaches to protein engineering permit the accommodation of several virus-like functions in single (hybrid) polypeptide chains $[16,25,32]$. In addition, since many microbial and non microbial organisms are being used as cell factories for therapeutic proteins [33], a wide spectrum of biological platforms,
C Biomed Central

() 2010 Vázquez and Villaverde; licensee BioMed Central Ltd. This is an Open Access article distributed under the terms of the Creative Commons Attribution License (http://creativecommons.org/licenses/by/2.0), which permits unrestricted use, distribution, and reproduction in any medium, provided the original work is properly cited. 
molecular tools and comparative expertise in alternative production strategies is available [34]. In particular, bacterial cells are generically good producers of diverse nanomaterials of medical application, including polymers, metal particles and protein particles [35].

The microbial production of protein particles of biomedical interest has been mainly focused on bacteriophages for peptide display, virus-like particles as immunogens and flagella and filamentous phages as templates for micro- and nanofabrication [35,36]. Apart from peptide-displaying filamentous phages, which have been widely explored for targeted delivery of DNA and conjugated drugs in cell culture but also in vivo [37-39], these particles have been in general hardly adaptable to cell-targeted drug delivery.

Ideally, polypeptides with specific functions relevant to drug delivery (mimicking those of viruses, [16]), should be engineered to self-assemble as nanoparticles with desired nanoscale properties, namely size and geometry, and produced in simple heterologous hosts. The construction of protein particles from their building blocks, as it occurs in natural viruses, can not be achieved by conventional nano-fabrication but through the selection of protein sequences promoting regular protein-protein interactions in absence of unspecific aggregation. In this regard, sets of both natural and non-natural amino acid sequences have been identified that promote peptide self-assembling in diverse patterns. Among them hydrogels, bilayers and nanofibers show important applications in tissue engineering but also in drug delivery [40-44]. Peptide self-assembling can be eventually controlled by $\mathrm{pH}$, temperature and other environment parameters [45-47], and it often involves the formation of amyloid-like, beta-sheet cross-molecular interactions [41] similar to those governing the formation of bacterial inclusion bodies [48-51]. Amyloid-like architecture is probable driving also the assembling of protein fibers formed by misfolding prone recombinant proteins in the cytoplasm of recombinant bacteria $[52,53]$. Interestingly, some of these short peptides have been successfully produced in bacteria by means of conventional recombinant DNA approaches, fused to carrier proteins or as tandem repeats to enhance their stability [44,54-56] (Figure 1).

Very few of these peptides have been yet incorporated to larger, modular protein constructs for drug delivery to form multifunctional, virus-like protein cages. However, a couple of examples from our own experience prove the feasibility of the concept. In this regard, polylysine stretches, commonly used as cationic peptides for DNA condensation [57], confer architectonic properties to engineered beta-galactodidases, which already contained several functional motives for cell receptor binding and nuclear delivery. These chimerical enzymes formed amorphous nanoparticles [58,59], and have been

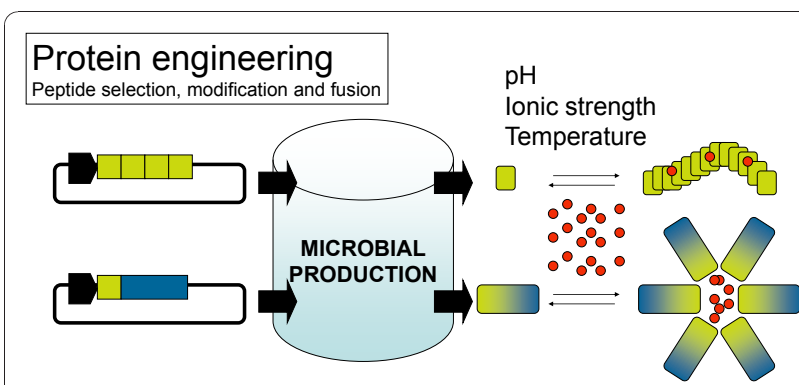

Figure 1 Self-assembling peptide sequences (yellow boxes) are usually identified from nature, obtained by trial-and-error protein engineering approaches or isolated from combinatorial libraries. Peptides can be produced in microbial cells as tandem repeats or fused to carrier proteins for further recovery and isolation by proteolysis. Eventually, self-assembling peptides can be produced as fused to multifunctional proteins (blue), to generate selforganizing artificial viruses. Ideally, the assembling of both single peptides and more complex protein building blocks into supramolecular constructs should be controlled in vitro by simple physicochemical parameters, to permit the incorporation of the cargo drug (in red).

proved to be excellent artificial viruses for in vivo gene delivery to the nervous system in ischemia models and for both histological and functional recovery of injured animals $[60,61]$. Also, poly-arginine peptides, again used by their DNA condensation properties promoted the self-assembling of scaffold green fluorescent proteins as monodisperse, highly regular $20 \mathrm{~nm}$-nanoparticles useful for DNA and protein delivery [62]. These particles are formed irrespective of the solubility exhibited by the protein under different storage conditions $[62,63]$, proving high regularity and consistence in their architectonic schemes. Interestingly, once exposure to cultured mammalian cells, the intracellular trafficking of these entities is extremely efficient, showing a fast and steady nuclear accumulation in fluorescent forms $[62,64]$. The sticky nature of cationic peptides, although not completely solved, does not seem to involve cross beta-sheet interactions.

These last results provide a valid proof of concept of the incorporation of self-assembling peptides to complex protein building blocks of artificial viruses (Figure 1), although this is still far from rational design. Moreover, steady conceptual advances in the biology of proteinprotein interactions and the easy bioproduction of chimerical proteins in microbial hosts, permit to envisage further progresses in the design of protein cages for drug delivery based on both protein engineering and the exploitation of microbial cell factories.

\section{Acknowledgements}

We appreciate the financial support received for the design and microbial production of recombinant proteins for biomedical applications from FISS (PS09/00165), MEC (BFU2010-17450, ACI2009-0919, IT2009-0021, EUI2008- 
03610), AGAUR (2005SGR-00956), CIBER de Bioingeniería, Biomateriales y Nanomedicina (CIBER-BBN), Spain, and from the European Science Foundation, which is also funded by the European Commission, Contract no. ERAS-CT-2003-980409 of the Sixth Framework Programme (ERANET-IB 08007).

\section{Author details}

${ }^{1}$ Institute for Biotechnology and Biomedicine, Universitat Autònoma de Barcelona, Bellaterra, 08193 Barcelona, Spain. ${ }^{2}$ Department of Genetics and Microbiology, Universitat Autònoma de Barcelona, Bellaterra, 08193 Barcelona, Spain. ${ }^{3} \mathrm{CIBER}$ de Bioingeniería, Biomateriales y Nanomedicina (CIBER-BBN), Bellaterra, 08193 Barcelona, Spain.

\section{Authors' contributions}

$\mathrm{EV}$ and $\mathrm{AV}$ have equally contributed to this work

\section{Competing interests}

The authors declare that they have no competing interests.

Received: 29 December 2010 Accepted: 30 December 2010

Published: 30 December 2010

\section{References}

1. Douglas KL: Toward Development of Artificial Viruses for Gene Therapy: A Comparative Evaluation of Viral and Non-viral Transfection. Biotechnol Prog 2008, 24:871-883.

2. Mastrobattista E, van der Aa MA, Hennink WE, Crommelin DJ: Artificial viruses: a nanotechnological approach to gene delivery. Nat Rev Drug Discov 2006, 5:115-121

3. Wagner E: Strategies to improve DNA polyplexes for in vivo gene transfer: will "artificial viruses" be the answer? Pharm Res 2004, 21:8-14.

4. Parveen S, Sahoo SK: Polymeric nanoparticles for cancer therapy. J Drug Target 2008, 16:108-123.

5. Kaasgaard T, Andresen TL: Liposomal cancer therapy: exploiting tumor characteristics. Expert Opin Drug Deliv 2010, 7:225-243.

6. Malam Y, Loizidou M, Seifalian AM: Liposomes and nanoparticles: nanosized vehicles for drug delivery in cancer. Trends Pharmacol Sci 2009, 30:592-599.

7. Singh S: Nanomedicine-nanoscale drugs and delivery systems. J Nanosci Nanotechnol 2010, 10:7906-7918.

8. Betancourt T, Brannon-Peppas L: Micro- and nanofabrication methods in nanotechnological medical and pharmaceutical devices. Int $J$ Nanomedicine 2006, 1:483-495.

9. Caldorera-Moore M, Guimard N, Shi L, Roy K: Designer nanoparticles: incorporating size, shape and triggered release into nanoscale drug carriers. Expert Opin Drug Deliv 2010, 7:479-495.

10. Tjalsma H: Identification of biomarkers for colorectal cancer through proteomics-based approaches. Expert Rev Proteomics 2010, 7:879-895.

11. Deonarain MP, Kousparou CA, Epenetos AA: Antibodies targeting cancer stem cells: a new paradigm in immunotherapy? MAbs 2009, 1:12-25

12. Ruoslahti E, Bhatia SN, Sailor MJ: Targeting of drugs and nanoparticles to tumors. J Cell Biol 2010, 188:759-768.

13. Gonzalez-Angulo AM, Hennessy BT, Mills GB: Future of personalized medicine in oncology: a systems biology approach. J Clin Oncol 2010, 28:2777-2783.

14. Bharali DJ, Mousa SA: Emerging nanomedicines for early cancer detection and improved treatment: current perspective and future promise. Pharmacol Ther 2010, 128:324-335.

15. Dietz GP, Bahr M: Delivery of bioactive molecules into the cell: the Trojan horse approach. Mol Cell Neurosci 2004, 27:85-131.

16. Aris $A$, Villaverde $A$ : Modular protein engineering for non-viral gene therapy. Trends Biotechnol 2004, 22:371-377.

17. Ferrer-Miralles N, Vazquez E, Villaverde A: Membrane-active peptides for non-viral gene therapy: making the safest easier. Trends Biotechnol 2008, 26:267-275.

18. Vives E, Schmidt J, Pelegrin A: Cell-penetrating and cell-targeting peptides in drug delivery. Biochim Biophys Acta 2008, 1786:126-138.

19. Martin ME, Rice KG: Peptide-guided gene delivery. AAPS J 2007, 9:E18-E29.

20. Aina $\mathrm{OH}$, Liu R, Sutcliffe JL, Marik J, Pan CX, Lam KS: From combinatorial chemistry to cancer-targeting peptides. Mol Pharm 2007, 4:631-651.
21. Beck A, Klinguer-Hamour C, Bussat MC, Champion T, Haeuw JF, Goetsch L, et al: Peptides as tools and drugs for immunotherapies. Journal of Peptide Science 2007, 13:588-602

22. Enback J, Laakkonen P: Tumour-homing peptides: tools for targeting, imaging and destruction. Biochem Soc Trans 2007, 35:780-783.

23. Balestrieri ML, Napoli C: Novel challenges in exploring peptide ligands and corresponding tissue-specific endothelial receptors. Eur J Cancer 2007, 43:1242-1250.

24. Fabre JW, Collins L: Synthetic peptides as non-viral DNA vectors. Curr Gene Ther 2006, 6:459-480.

25. Vazquez E, Ferrer-Miralles N, Mangues R, Corchero JL, Schwartz S Jr, Villaverde A: Modular protein engineering in emerging cancer therapies. Curr Pharm Des 2009, 15:893-916.

26. Brown KC: Peptidic tumor targeting agents: the road from phage display peptide selections to clinical applications. Curr Pharm Des 2010, 16:1040-1054.

27. Sidhu SS: Phage display in pharmaceutical biotechnology. Curr Opin Biotechnol 2000, 11:610-616.

28. Deutscher SL: Phage display in molecular imaging and diagnosis of cancer. Chem Rev 2010, 110:3196-3211.

29. Tanaka T, Kokuryu Y, Matsunaga T: Novel method for selection of antimicrobial peptides from a phage display library by use of bacterial magnetic particles. Appl Environ Microbiol 2008, 74:7600-7606.

30. Uchida M, Klem MT, Allen M, Suci P, Flenniken M, Varpness Z, et al: Biological containers: Protein cages as multifunctional nanoplatforms. Adv Mater 2007, 19:1025-1042.

31. Maham A, Tang Z, Wu H, Wang J, Lin Y: Protein-Based Nanomedicine Platforms for Drug Delivery. Small 2009, 5:1706-1721.

32. Vazquez E, Ferrer-Miralles N, Villaverde A: Peptide-assisted traffic engineering for nonviral gene therapy. Drug Discov Today 2008, 13:1067-1074.

33. Ferrer-Miralles N, Domingo-Espin J, Corchero JL, Vazquez E, Villaverde A: Microbial factories for recombinant pharmaceuticals. Microb Cell Fact 2009, 8:17.

34. Gasser B, Saloheimo M, Rinas U, Dragosits M, Rodriguez-Carmona E, Baumann $\mathrm{K}$, et al: Protein folding and conformational stress in microbial cells producing recombinant proteins: a host comparative overview. Microb Cell Fact 2008, 7:11.

35. Rodriguez-Carmona E, Villaverde A: Nanostructured bacterial materials for innovative medicines. Trends Microbiol 2010, 18:423-430.

36. Villaverde A: Nanotechnology, bionanotechnology and microbial cell factories. Microb Cell Fact 2010, 9:53.

37. Bar H, Yacoby I, Benhar I: Killing cancer cells by targeted drug-carrying phage nanomedicines. BMC Biotechnol 2008, 8:37.

38. Larocca D, Burg MA, Jensen-Pergakes K, Ravey EP, Gonzalez AM, Baird A Evolving phage vectors for cell targeted gene delivery. Curr Pharm Biotechnol 2002, 3:45-57.

39. Du B, Han $H$, Wang $Z$, Kuang $L$, Wang $L, Y u L$, et al: targeted drug delivery to hepatocarcinoma in vivo by phage-displayed specific binding peptide. Mol Cancer Res 2010, 8:135-144.

40. Zhao Y, Tanaka M, Kinoshita T, Higuchi M, Tan T: Self-assembling peptide nanofiber scaffolds for controlled release governed by gelator design and guest size. J Control Release 2010, 147:392-399.

41. Zhao $Y$, Tanaka M, Kinoshita $T$, Higuchi M, Tan $T$ : Nanofibrous scaffold from self-assembly of beta-sheet peptides containing phenylalanine for controlled release. J Control Release 2010, 142:354-360.

42. Gelain F, Unsworth LD, Zhang S: Slow and sustained release of active cytokines from self-assembling peptide scaffolds. J Control Release 2010, 145:231-239.

43. Kyle S, Aggeli A, Ingham E, McPherson MJ: Production of self-assembling biomaterials for tissue engineering. Trends Biotechnol 2009, 27:423-433.

44. Kyle S, Aggeli A, Ingham E, McPherson MJ: Recombinant self-assembling peptides as biomaterials for tissue engineering. Biomaterials 2010, 31:9395-9405.

45. Yan F, Zhang Y, Kim KS, Yuan HK, Vo-Dinh T: Cellular uptake and photodynamic activity of protein nanocages containing methylene blue photosensitizing drug. Photochem Photobiol 2010, 86:662-666.

46. Bessa PC, Machado R, Nurnberger S, Dopler D, Banerjee A, Cunha AM, et al: Thermoresponsive self-assembled elastin-based nanoparticles for delivery of BMPs. J Control Release 2010, 142:312-318. 
47. Huang $H$, Sun XS: Rational design of responsive self-assembling peptides from native protein sequences (dagger). Biomacromolecules 2010, 11:3390-3394

48. Ventura S, Villaverde A: Protein quality in bacterial inclusion bodies. Trends Biotechnol 2006, 24:179-185.

49. Martinez-Alonso M, Gonzalez-Montalban N, Garcia-Fruitos E, Villaverde A: Learning about protein solubility from bacterial inclusion bodies. Microb Cell Fact 2009, 8:4.

50. Garcia-Fruitos E, Villaverde A: Friendly production of bacterial inclusion bodies. Korean J Chem Eng 2010, 27:385-389.

51. Carrio M, Gonzalez-Montalban N, Vera A, Villaverde A, Ventura S: Amyloidlike properties of bacterial inclusion bodies. J Mol Biol 2005, 347:1025-1037.

52. Schrodel A, de Marco A: Characterization of the aggregates formed during recombinant protein expression in bacteria. BMC Biochem 2005, 6:10.

53. Martinez-Alonso M, Gonzalez-Montalban N, Garcia-Fruitos E, Villaverde A: The functional quality of soluble recombinant polypeptides produced in Escherichia coli is defined by a wide conformational spectrum. Appl Environ Microbiol 2008, 101:1353-1358.

54. Hartmann BM, Kaar W, Falconer RJ, Zeng B, Middelberg AP: Expression and purification of a nanostructure-forming peptide. J Biotechnol 2008, 135:85-91.

55. Hartmann BM, Kaar W, Yoo IK, Lua LH, Falconer RJ, Middelberg AP: The chromatography-free release, isolation and purification of recombinant peptide for fibril self-assembly. Biotechnol Bioeng 2009, 104:973-985.

56. Riley JM, Aggeli A, Koopmans RJ, McPherson MJ: Bioproduction and characterization of a pH responsive self-assembling peptide. Biotechnol Bioeng 2009, 103:241-251.

57. Saccardo P, Villaverde A, Gonzalez-Montalban N: Peptide-mediated DNA condensation for non-viral gene therapy. Biotechnol Adv 2009, 27:432-438.

58. Aris $A$, Villaverde $A$ : Molecular organization of protein-DNA complexes for cell-targeted DNA delivery. Biochem Biophys Res Commun 2000, 278:455-461.

59. Aris A, Villaverde A: Engineering nuclear localization signals in modular protein vehicles for gene therapy. Biochem Biophys Res Commun 2003, 304:625-631.

60. Peluffo $H$, Acarin L, Aris A, Gonzalez P, Villaverde A, Castellano B, et al: Neuroprotection from NMDA excitotoxic lesion by $\mathrm{Cu} / \mathrm{Zn}$ superoxide dismutase gene delivery to the postnatal rat brain by a modular protein vector. BMC Neurosci 2006, 7:35.

61. Peluffo H, Aris A, Acarin L, Gonzalez B, Villaverde A, Castellano B: Nonviral gene delivery to the central nervous system based on a novel integrintargeting multifunctional protein. Hum Gene Ther 2003, 14:1215-1223.

62. Vazquez E, Roldán M, Diez-Gil C, Unzueta U, Domingo-Espin J, Cedano J, et al: Protein nanodisk assembling and intracellular trafficking powered by an arginine-rich (R9) peptide. Nanomedicine 2010, 5:259-268.

63. Toledo-Rubio V, Vazquez E, Platas G, Domingo-Espin J, Unzueta U, Steinkamp E, et al: Protein aggregation and soluble aggregate formation screened by a fast microdialysis assay. J Biomol Screen 2010, 15:453-457.

64. Vazquez E, Cubarsi R, Unzueta U, Roldan M, Domingo-Espin J, FerrerMiralles $\mathrm{N}$, et al: Internalization and kinetics of nuclear migration of protein-only, arginine-rich nanoparticles. Biomaterials 2010, 31:9333-9339.

doi:10.1186/1475-2859-9-101

Cite this article as: Vázquez and Villaverde: Engineering building blocks for self-assembling protein nanoparticles. Microbial Cell Factories 2010 9:101.

\section{Submit your next manuscript to BioMed Central and take full advantage of:}

- Convenient online submission

- Thorough peer review

- No space constraints or color figure charges

- Immediate publication on acceptance

- Inclusion in PubMed, CAS, Scopus and Google Scholar

- Research which is freely available for redistribution 